Received: 1 Mei 2021

Revised: 11 Juni 2021

Accepted: 23 Juni 2021

Published: 30 Juni 2021

\title{
Perbandingan Spatial Autoregressive Model dan Spatial Error Model dalam Pemodelan Indeks Pembangunan Manusia di Provinsi Jawa Timur
}

\author{
Desi Rahmawati $^{1, \text { a) }}$, Hardian Bimanto $^{1, \text { b) }}$ \\ ${ }^{1}$ Program Studi Magister Kesehatan Masyarakat Minat Biostatistika, Univerrsitas Airlangga, Surabaya \\ Email: a)desie.rahmawati-2019@fkm.unair.ac.id, ${ }^{b}$ hardian.bimanto-2019@fkm.unair.ac.id
}

\begin{abstract}
Human Development Index (HDI) is an indicator to measure the success of efforts to develop the quality of human life that have been achieved. The growth of HDI can be influenced by geographic factors, the large number of HDI figures in an area can affect theHDI value in adjacent areas. Geographical factors are thought to influence and give spatial dependency effects on the HDI value in East Java Province. This study aims to modeling factors that influence HDI in East Java Province. The observation units in this study were 38 districts/cities in East Java Province. The data used are secondary data from the Central Statistics Agency of East Java in 2017. The method of analysis used in this study is Spatial Autoregressive Model (SAR) and Spatial Error Model (SEM) methods. The results showed that the value of Lagrange Multiplier (lag) and Lagrange Multiplier (error) indicates there is a lag and error dependency. The predictor variables that significantly affect the HDI value in the SAR and SEM models include Life Expectancy, Mean Years School, Expected Years Schools and People's Purchasing Power. Based on the results, it was found that SEM model with the highest $\mathrm{R}^{2}$ value and the smallest AIC value. The SEM model is better used to analyze the HDI value in East Java Province compared to SAR model and OLS regression model.
\end{abstract}

Keywords: human development index, spatial autoregressive model, spatial error model.

\begin{abstract}
Abstrak
Indeks Pembangunan Manusia (IPM) merupakan indikator untuk mengukur keberhasilan upaya pembangunan kualitas hidup manusia yang telah dicapai. Pertumbuhan IPM di suatu wilayah dapat dipengaruhi oleh faktor geografis yaitu besarnya angka IPM di suatu wilayah dapat memengaruhi angka IPM pada wilayah yang berdekatan sehingga faktor geografis diduga dapat memengaruhi dan memberikan efek dependensi spasial pada nilai IPM di Provinsi Jawa Timur. Penelitian ini bertujuan untuk melakukan pemodelan pada faktor yang berpengaruh terhadap Indeks Pembangunan Manusia di Provinsi Jawa Timur. Unit pengamatan pada penelitian ini adalah 38 kabupaten/kota di Provinsi Jawa Timur. Data yang digunakan adalah data sekunder dari Badan Pusat Statistik Jawa Timur tahun 2017. Metode analisis yang digunakan dalam penelitian ini adalah metode Spatial Autoregressive Model (SAR) dan Spatial Error Model (SEM). Hasil penelitian menunjukkan bahwa berdasarkan nilai uji Lagrange Multiplier (lag) dan Lagrange Multiplier (error) terdapat dependensi lag dan error. Variabel prediktor yang secara signifikan berpengaruh terhadap nilai IPM pada model SAR dan SEM antara lain Angka Harapan Hidup, Rata-rata Lama Sekolah, Angka Harapan Lama Sekolah dan Kemampuan daya beli masyarakat. Berdasarkan hasil penelitian didapatkan model SEM dengan nilai $R^{2}$ terbesar dan nilai AIC terkecil sehingga model SEM lebih baik digunakan untuk menganalisis nilai IPM di Provinsi Jawa Timur dibandingkan model SAR dan model regresi OLS.
\end{abstract}

Kata-kata kunci: index pembangunan manusia, spatial autoregressive model, spatial error model. 


\section{PENDAHULUAN}

Indeks Pembangunan Manusia (IPM) atau Human Development Index (HDI) merupakan indikator penting untuk mengukur keberhasilan dalam upaya membangun kualitas hidup manusia yang telah dicapai. IPM dapat digunakan untuk menentukan peringkat atau level pembangunan suatu wilayah atau negara. IPM pada dasarnya adalah nilai yang menunjukkan tingkat kesejahteraan masyarakat yang dibentuk dari 3 (tiga) dimensi dasar, yaitu usia yang panjang dan hidup sehat yang dapat diukur dengan Angka Harapan Hidup (AHH), pengetahuan atau tingkat pendidikan yang dapat diukur dengan lamanya sekolah (dalam tahun) yang diharapkan atau Angka Harapan Lama Sekolah (AHLS) dan angka partisipasi pendidikan yang telah ditamatkan (dalam tahun) atau Rata-Rata Lama Sekolah (RLS), serta standar hidup layak yang diukur dengan dengan pendekatan Produk Domestik Bruto (PDRB) per Kapita pada tingkat konsumsi riil per kapita atau kemampuan daya beli masyarakat (BPS, 2019).

Pertumbuhan IPM di suatu wilayah dapat dipengaruhi oleh faktor geografis yaitu besarnya angka IPM di suatu wilayah dapat memengaruhi angka IPM pada wilayah yang berdekatan. Sehingga faktor geografis (lokasi/wilayah) diduga dapat memengaruhi dan memberikan efek ketergantungan spasial (wilayah) pada angka IPM. Hal ini dapat dilihat dari angka IPM di daerah perkotaan lebih tinggi dibandingkan di daerah kabupaten di Provinsi Jawa Timur. Berdasarkan data Badan Pusat Statistik Provinsi Jawa Timur tahun 2017 angka IPM tertinggi di Kota Surabaya yaitu sebesar 81,07\% dan angka IPM terendah di Kabupaten Sampang yaitu sebesar 59,9\%. Angka IPM di Provinsi Jawa Timur pada tahun 2017 lebih rendah dibandingkan provinsi lainnya yang berada di pulau Jawa yaitu 70,27\%. Sehingga hal ini menjadi dasar penggunaan analisis spasial untuk mengidentifikasi variabel-variabel yang memengaruhi IPM di Provinsi Jawa Timur.

Metode analisis spasial yang dapat digunakan untuk memodelkan pengaruh variabel prediktor terhadap variabel respon dengan memperhatikan efek spasial adalah regresi spasial. Berdasarkan tipe data, regresi spasial terdiri dari regresi spasial dengan pendekatan titik dan pendekatan area. Regresi spasial dengan pendekatan titik digunakan untuk menyelesaikan kasus yang mengandung heterogenitas spasial sedangakan spasial area digunakan untuk menyelesaikan kasus yang mengandung dependensi spasial (ketergantungan wilayah). Terdapat beberapa metode analisis spasial dengan pendekatan area yaitu Spatial Autoregressive Model (SAR) dan Spatial Error Model (SEM). Model SAR merupakan model yang mengkombinasikan antara model regresi linear dengan lag spasial pada variabel respon. Lag spasial muncul saat nilai observasi variabel respon pada suatu lokasi berkorelasi dengan nilai observasi variabel respon di lokasi sekitarnya (terdapat korelasi spasial antar variabel respon). Sedangkan model SEM digunakan apabila nilai error pada suatu lokasi berkorelasi dengan nilai error di lokasi sekitarnya (terdapat korelasi spasial antar error) (Anselin, 1988).

Berdasarkan latar belakang tersebut penelitian ini bertujuan untuk melakukan pemodelan pada faktor yang berpengaruh terhadap Indeks Pembangunan Manusia di Provinsi Jawa Timur dengan menggunakan metode Spatial Autoregressive Model (SAR) dan Spatial Error Model (SEM).

\section{METODOLOGI}

\section{Data}

Data yang digunakan dalam penelitian ini adalah data sekunder yang bersumber dari Badan Pusat Statistik (BPS) Provinsi Jawa Timur tahun 2017. Unit pengamatan yang digunakan pada penelitian ini adalah 38 kabupaten/kota di Provinsi Jawa Timur. Terdapat 4 variabel prediktor (X) dan 1 variabel respon (Y) dalam penelitian ini, antara lain sebagai berikut:

TABEL 1. Variabel Penelitian

\begin{tabular}{clc}
\hline Variabel & \multicolumn{1}{c}{ Keterangan } & Satuan \\
\hline $\mathrm{Y}$ & Nilai Indeks Pembangunan Manusia (IPM) & Persen \\
$\mathrm{X}_{1}$ & Angka Harapan Hidup (AHH) & Tahun \\
$\mathrm{X}_{2}$ & Rata-Rata Lama Sekolah (RLS) & Tahun \\
$\mathrm{X}_{3}$ & Angka Harapan Lama Sekolah (HLS) & Tahun \\
$\mathrm{X}_{4}$ & Pengeluaran perkapita riil disesuaikan (kemampuan daya beli) & Ribu Rupiah \\
\hline
\end{tabular}




\section{Metode Penelitian}

Analisis data yang digunakan dalam penelitian ini terdiri dari dua macam yaitu analisis deskriptif dan analisis inferensial. Analisis deskriptif digunakan untuk menggambarkan persebaran nilai Indeks Pembangunan Manusia di Provinsi Jawa Timur berdasarkan 4 kategori yang dapat dilihat pada tabel 2. Sedangkan analisis inferensial yang digunakan dalam penelitian ini adalah metode analisis spasial dengan pendekatan area yaitu metode Spatial Autoregressive Model (SAR) dan Spatial Error Model (SEM).

TABEL 2. Kategori Nilai Indeks Pembangunan Manusia

\begin{tabular}{cl}
\hline Nilai IPM & \multicolumn{1}{c}{ Kategori } \\
\hline IPM $<60$ & Daerah dengan tingkat pembangunan manusia yang rendah \\
$60 \leq$ IPM $<70$ & Daerah dengan tingkat pembangunan manusia yang sedang \\
$70 \leq$ IPM $<80$ & Daerah dengan tingkat pembangunan manusia yang tinggi \\
IPM $>80$ & Daerah dengan tingkat pembangunan manusia yang sangat tinggi \\
\hline
\end{tabular}

Adapun tahapan analisis data dalam penelitian ini antara lain sebagai berikut:

1. Melakukan eksplorasi data dengan peta tematik untuk mengetahui pola persebaran nilai Indeks Pembangunan Manusia di Provinsi Jawa Timur.

2. Melakukan analisis regresi dengan metode Ordinary Least Square (OLS).

3. Identifikasi keberadaan efek spasial dengan menggunakan uji Moran's I dan Lagrange Multiplier untuk uji dependensi spasial dan uji Breusch-Pagan untuk uji heterogenitas spasial.

4. Menentukan matriks pembobot $W_{i j}$.

5. Melakukan pemodelan dengan metode SAR dan SEM yaitu melakukan estimasi parameter dan pengujian signifikansi parameter.

6. Menentukan model terbaik berdasarkan kriteria koefisien determinasi $\left(R^{2}\right)$ dan nilai Akaike's Information Criteria (AIC).

\section{Uji Efek Spasial}

Menurut Anselin (1988) terdapat dua macam efek spasial yaitu efek dependensi spasial yang disebabkan oleh adanya korelasi antar wilayah dan efek heterogenitas spasial yang disebabkan oleh keragaman karakteristik antar wilayah.

1. Uji Dependensi spasial

Efek dependensi spasial (ketergantungan spasial) muncul berdasarkan hukum Tobler I yang dikutip oleh Fauzi (2016) yaitu segala sesuatu saling berhubungan dengan hal yang lain tetapi sesuatu yang lebih dekat mempunyai pengaruh yang lebih besar. Penyelesaian yang dilakukan jika ada efek dependensi spasial adalah dengan pendekatan area. Untuk mendeteksi adanya efek dependensi spasial digunakan uji Lagrange Multiplier (Anselin,1988). Pengujian hipotesis Lagrange Multiplier adalah:

a. $\mathrm{H}_{0}: \rho=0$ (tidak ada dependensi lag spasial)

$\mathrm{H}_{1}: \rho \neq 0$ (ada dependensi lag spasial)

b. $\mathrm{H}_{0}: \lambda=0$ (tidak ada dependensi error spasial)

$\mathrm{H}_{1}: \lambda \neq 0$ (ada dependensi error spasial)

c. $\mathrm{H}_{0}: \rho, \lambda=0$ (tidak ada dependensi spasial lag dan error)

$\mathrm{H}_{1}: \rho, \lambda \neq 0$ (ada dependensi spasial lag dan error)

Statistik uji yang digunakan adalah:

Untuk spasial lag (SAR)

$$
L M_{\rho}=\frac{\left[e^{\prime} W Y /\left(e e^{\prime} / n\right)\right]^{2}}{D}
$$


dimana

$$
D=\left[\frac{(W X \beta)^{\prime}\left(I-X\left(X^{\prime} X\right)^{-1} X^{\prime}\right)(W X \beta)}{\sigma^{2}}\right]+\operatorname{tr}\left(W^{\prime} W+W W\right)
$$

Keterangan:

e : Vektor error model regresi

$\mathrm{n}$ : Banyaknya observasi

$\mathrm{W}$ : Matriks pembobot spasial berukuran (nxn)

$\mathrm{X}$ : Matriks variabel bebas berukuran $(\mathrm{n} \mathrm{x}(\mathrm{p}+1))$

$\mathrm{Y}$ : Matriks variabel respon yang berukuran $(\mathrm{nx} 1)$

$\beta$ : Vektor koefisien parameter regresi berukuran $(\mathrm{p}+1) \mathrm{x} 1$

I : Matriks identitas

$\sigma^{2}$ : Estimasi varians error model regresi

Pengambilan keputusannya yaitu tolak $\mathrm{H}_{0}$ apabila $\mathrm{LM}_{\rho}>\chi_{(\mathrm{q})}^{2}$ atau $p$-value $<\alpha$ yang berarti terdapat efek dependensi spasial lag

Untuk spasial error (SEM)

$$
L M_{\lambda}=\frac{\left[e^{\prime} W e /\left(e e^{\prime} / n\right)\right]^{2}}{\operatorname{tr}\left(W^{\prime} W+W W\right)}
$$

Keterangan:

e : Vektor error model regresi

$\mathrm{n}$ : Banyaknya observasi

$\mathrm{W}$ : Matriks pembobot spasial berukuran (nxn)

Pengambilan keputusannya yaitu tolak $\mathrm{H}_{0}$ apabila $\mathrm{LM}_{\lambda}>\chi^{2}{ }_{(\mathrm{q})}$ atau $p$-value $<\alpha$ yang berarti terdapat efek dependensi spasial error.

2. Uji Heterogenitas Spasial

Efek heterogenitas (keragaman spasial) adalah efek yang menunjukkan adanya keragaman antar lokasi sehingga setiap lokasi mempunyai struktur dan parameter hubungan yang berbeda. Pengujian efek keragaman spasial menggunakan uji Breusch-Pagan (Anselin,1988). Hipotesis dalam uji Breusch-Pagan adalah:

$\mathrm{H}_{0}: \sigma_{1}^{2}=\sigma_{2}^{2}=\cdots=\sigma_{n}^{2}=\sigma^{2}$ (tidak terdapat keragaman antar wilayah/varians sama) $\mathrm{H}_{1}$ : minimal ada satu $\sigma_{1}^{2} \neq \sigma^{2}$ (terdapat keragaman antar wilayah/bersifat heteroskedastisitas)

Statistik uji yang digunakan adalah:

$$
\mathrm{BP}=(1 / 2) \mathrm{f}^{\mathrm{T}} \mathrm{Z}\left(\mathrm{Z}^{\mathrm{T}} \mathrm{Z}\right)^{-1} \mathrm{Z}^{\mathrm{T}} \mathrm{f} \sim \chi^{2}(\mathrm{p})
$$

dimana $\mathrm{Z}$ adalah matriks berukuran $\mathrm{nxn}(\mathrm{p}+1)$ yang berisi vektor yang sudah dinormal standarkan (z) untuk setiap observasi dan elemen vektor $\mathrm{f}$ adalah:

$$
\mathrm{f}=\left(\frac{e_{i}^{2}}{\sigma^{2}}-1\right)
$$

dimana $e_{\mathrm{i}}$ adalah kuadrat error untuk pengamatan ke- $i$. Pengambilan keputusan yaitu tolak $\mathrm{H}_{0}$ apabila $\mathrm{Bp}>\chi_{(\mathrm{p})}^{2}$ atau $p$-value $<\alpha$ yang berarti terdapat keragaman antar wilayah. 


\section{Spatial Autoregressive Model (SAR)}

Spesifikasi lag spasial ditandai dengan dimasukkanya variabel baru di sisi kanan dari persamaan. Model spasial autoregressive terbentuk apabila $\rho \neq 0$ dan $\lambda=0$, sehingga model ini mengasumsikan bahwa proses autoregressive pada variabel respon. Berikut persamaan model SAR (Lesage, 2009):

$$
Y=\rho W Y+X \beta+\varepsilon
$$

dimana

$\mathrm{Y}$ : Matriks variabel respon yang berukuran $(\mathrm{nx} 1)$

$\mathrm{X}$ : Matriks variabel bebas berukuran $(\mathrm{n} \times(\mathrm{p}+1))$

$\rho$ : koefisien autoregresi lag spasial

$\beta$ : vektor koefisien parameter regresi berukuran $(\mathrm{p}+1) \mathrm{x} 1$

$\varepsilon$ : vektor error berukuran $\mathrm{n} \times 1$ yang berdistribusi normal dengan rata-rata nol dan varians $\sigma^{2} \mathrm{I}$

$\mathrm{W}$ : matriks pembobot spasial yang berukuran $\mathrm{n} \times \mathrm{n}$

\section{Spatial Error Model (SEM)}

Model spasial error terbentuk apabila $\lambda \neq 0$ dan $\rho=0$, sehingga model ini mengasumsikan bahwa proses autoregressive hanya pada error model. Model SEM ditunjukan dengan persamaan berikut ini:

$$
\mathrm{Y}=\mathrm{X} \beta+\lambda \mathrm{Wu}+\varepsilon
$$

dimana

Y : Matriks variabel respon yang berukuran $(\mathrm{nx} 1)$

$\mathrm{X}$ : Matriks variabel bebas berukuran $(\mathrm{n} \mathrm{x}(\mathrm{p}+1))$

$\beta$ : vektor koefisien parameter regresi berukuran $(\mathrm{p}+1) \mathrm{x} 1$

$\lambda$ : koefisien autoregresi lag pada error yang bernilai $|\lambda|<1$

$\mathrm{W}$ : matriks pembobot spasial yang berukuran $\mathrm{n} \times \mathrm{n}$

$\mathrm{u}$ : vektor error yang diasumsikan mengandung autokorelasi berukuran $\mathrm{n} \times 1$

$\varepsilon$ : vektor error berukuran n 1 yang berdistribusi normal dengan rata-rata nol dan varians $\sigma^{2} \mathrm{I}$

\section{HASIL DAN PEMBAHASAN}

\section{Gambaran Nilai Indeks Pembangunan Manusia (IPM) di Provinsi Jawa Timur}

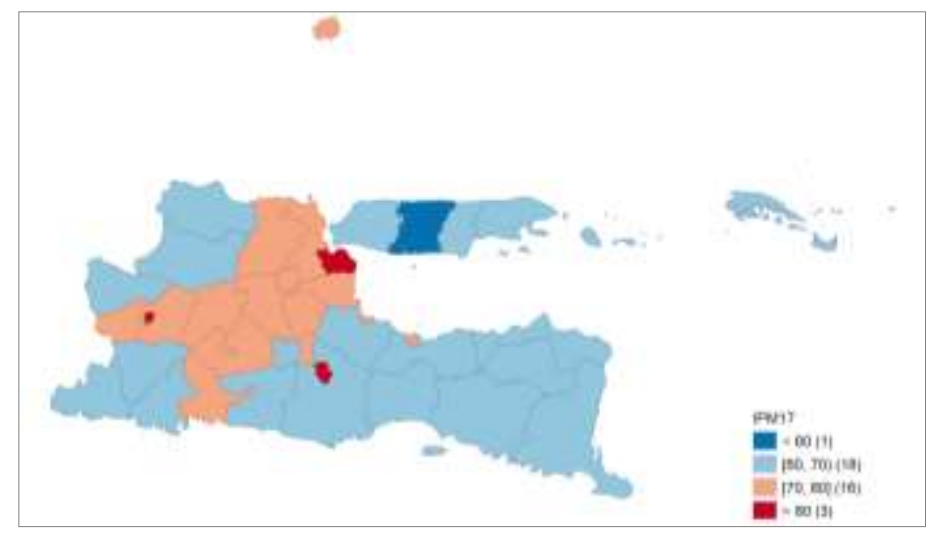

GAMBAR 1. Peta Tematik Indeks Pembangunan Manusia di Provinsi Jawa Timur

GAMBAR 1 menunjukkan peta persebaran nilai Indeks Pembangunan Masyarakat di Provinsi Jawa Timur berdasarkan 4 kategori. Kategori rendah dengan nilai IPM $<60 \%$ ditunjukkan dengan warna biru 
gelap. Kategori sedang dengan nilai IPM antara 60\%-70\% ditunjukkan dengan warna biru terang. Kategori tinggi dengan nilai IPM 70\%-80\% ditunjukkan dengan warna coklat terang. Sedangkan kategori tinggi dengan nilai IPM > 80\% ditunjukkan dengan warna coklat tua. Wilayah yang masuk dalam kategori rendah adalah Kabupaten Sampang sedangkan wilayah yang masuk kategori sangat tinggi adalah Kota Surabaya, Kota Malang dan Kota Madiun. Berdasarkan peta tematik nilai IPM di Provinsi Jawa Timur memiliki ketergantungan antar wilayah. Hal ini dapat dilihat dari wilayah yang berada dalam kategori rendah yaitu Kabupaten Sampang dikelilingi oleh wilayah yang berada dalam kategori sedang yaitu Kabupaten bangkalan dan Kabupaten Pamekasan. Wilayah dalam kategori sangat tinggi yaitu Kota Surabaya dikelilingi oleh wilayah yang berada dalam kategori tinggi yaitu Kabupaten Gresik dan Kabupaten Sidoarjo. Wilayah dalam kategori sangat tinggi lainnya yaitu Kota Madiun juga dikelilingi oleh wilayah yang berada dalam kategori tinggi yaitu Kabupaten Madiun dan Kabupaten Magetan. Berdasarkan warna yang ditampilkan dalam peta tematik nilai IPM Provinsi Jawa Timur pada wilayah dengan kategori tinggi yang ditunjukkan dengan warna coklat muda mengumpul di tengah dan membentuk kelompok. Untuk membuktikan adanya efek dependensi spasial (ketergantungan antar wilayah) pada nilai IPM di Provinsi Jawa Timur selanjutnya dilakukan uji statistik menggunakan uji Moran's Index dan Lagrange Multiplier.

\section{Model Regresi Ordinary Least Square (OLS)}

TABEL 3. Hasil Uji Parameter Regresi Ordinary Least Square (OLS) secara Simultan

\begin{tabular}{lccccc}
\hline \multicolumn{1}{c}{ Model } & Sum of Square & DF & Mean Square & F-statistic & p-value \\
\hline Regression & 1042,107 & 4 & 260,527 & 3687,501 & 0,00000 \\
Residual & 2,331 & 33 & 0,071 & & \\
Total & 1044,438 & 37 & & & \\
\hline
\end{tabular}

Berdasarkan hasil uji parameter regresi OLS secara simultan (serentak) yang tersaji dalam TABEL 3 , dapat dilihat bahwa nilai $\mathrm{F}_{\text {hitung }}>\mathrm{F}_{(\alpha, \mathrm{p}, \mathrm{n}-\mathrm{p}-1)}$, diketahui bahwa nilai $\mathrm{F}_{(\alpha, \mathrm{p}, \mathrm{n}-\mathrm{p}-1)}=2,65887$ dan $p$-value $<\alpha$ 0,05 . Maka keputusannya adalah $\mathrm{H}_{0}$ ditolak yang berarti variabel prediktor secara serentak berpengaruh signifikan terhadap variabel respon. Nilai koefisien determinasi yang didapatkan adalah sebesar 0,997768 yang berarti bahwa kemampuan variabel prediktor dalam menjelaskan varians dari variabel respon adalah sebesar $99,78 \%$ dan sisanya dijelaskan oleh variabel lain yang tidak diteliti.

TABEL 4. Hasil Uji Parameter Regresi Ordinary Least Square (OLS) secara Parsial

\begin{tabular}{ccccc}
\hline Variabel & Koefisien & Standard Error & t-value & $\boldsymbol{p}$-value \\
\hline Intercept & 5,91196 & 2,56384 & 2,3059 & 0,02754 \\
$\mathrm{X}_{1}$ & 0,45076 & 0,03444 & 13,0875 & 0,00000 \\
$\mathrm{X}_{2}$ & 1,37610 & 0,08344 & 16,4906 & 0,00000 \\
$\mathrm{X}_{3}$ & 1,01393 & 0,08470 & 11,9701 & 0,00000 \\
$\mathrm{X}_{4}$ & 0,00080 & $4,47035 \mathrm{e}-005$ & 17,9008 & 0,00000 \\
\hline
\end{tabular}

TABEL 4 menunjukkan bahwa berdasarkan hasil uji parameter regresi OLS secara parsial, variabel prediktor $\mathrm{X}_{1}(\mathrm{AHH}), \mathrm{X}_{2}(\mathrm{RLS}), \mathrm{X}_{3}$ (AHLS) dan $\mathrm{X}_{4}$ (Kemampuan daya beli) secara parsial berpengaruh signifikan terhadap variabel respon Y (IPM) dengan nilai $t_{\text {hitung }}>t_{(\alpha, n-p)}$, diketahui nilai $t_{(\alpha, n-p)}=2,03225$ dan $p$-value $<\alpha 0,05$. Model regresi OLS yang terbentuk adalah sebagai berikut:

$$
y=5,91196+0,45076\left(X_{1}\right)+1,3761\left(X_{2}\right)+1,01393\left(X_{3}\right)+0,0008\left(X_{4}\right)
$$

Interpretasi dari model regresi tersebut adalah jika variabel lain dianggap konstan, maka setiap kenaikan 1 satuan variabel $\mathrm{X}_{1}$ (Angka Harapan Hidup) maka dapat meningkatkan nilai IPM sebesar 0,45076. Jika variabel lain dianggap konstan maka setiap kenaikan 1 satuan variabel $\mathrm{X}_{2}$ (Rata-Rata Lama Sekolah) maka dapat meningkatkan nilai IPM sebesar 1,3761. Setiap kenaikan 1 satuan variabel $\mathrm{X}_{3}$ (Angka Harapan Lama Sekolah) maka dapat meningkatkan nilai IPM sebesar 1,01393 jika variabel 
lain dianggap konstan. Setiap kenaikan 1 satuan variabel $\mathrm{X}_{4}$ (Kemampuan daya beli) maka dapat meningkatkan nilai IPM sebesar 0,0008 jika variabel lain dianggap konstan.

\section{Uji Efek Spasial}

TABEL 5. Hasil Uji Efek Dependensi Spasial dan Heterogenitas Spasial

\begin{tabular}{lcc}
\hline \multicolumn{1}{c}{ Uji } & Nilai & p-value \\
\hline Moran's I & 0,3150 & 0,00325 \\
Breusch Pagan & 8,2145 & 0,08403 \\
\hline
\end{tabular}

Berdasarkan hasil uji efek spasial pada TABEL 5 dapat dilihat bahwa nilai Moran's $I \neq 0$ dan nilai $\mathrm{Z}_{\text {hitung }}(2,9431)>\mathrm{Z}_{\alpha / 2}(1,96)$ dan $p$-value $<\alpha 0,05$. Maka keputusannya adalah $\mathrm{H}_{0}$ ditolak yang berarti ada autokorelasi (ketergantungan) antar wilayah. Sedangkan nilai uji Breusch-Pagan (BP) $>X_{\alpha, p}^{2}$ diketahui nilai $\mathrm{X}_{\alpha, \mathrm{p}}^{2}=9,48773$ dan $p$-value $<\alpha 0,05$. Maka keputusannya adalah gagal menolak $\mathrm{H}_{0}$ yang berarti tidak terdapat keragaman antar wilayah sehingga dapat disimpulkan bahwa dalam pemodelan nilai IPM di Provinsi Jawa Timur mengandung efek spasial yaitu dependensi spasial. Hal ini berarti model OLS tidak cocok untuk digunakan sehingga penyelesaian dapat dilakukan menggunakan analisis spasial dengan pendekatan area.

TABEL 6. Hasil Uji Lagrange Multiplier

\begin{tabular}{lcc}
\hline \multicolumn{1}{c}{ Uji } & Nilai & p-value \\
\hline Lagrange Multiplier (lag) & 4,8854 & 0,02708 \\
Lagrange Multiplier (error) & 5,3066 & 0,02125 \\
\hline
\end{tabular}

TABEL 6 menunjukkan bahwa hasil identifikasi dependensi lag dan error dengan menggunakan uji Lagrange Multiplier menunjukkan bahwa $p$-value dari masing-masing uji Lagrange Multiplier $<\alpha 0,05$. Hal ini berarti bahwa terdapat dependensi lag spasial dan dependensi error spasial sehingga perlu dilakukan pemodelan dengan metode Spatial Autoregressive Model (SAR) dan Spatial Error Model (SEM).

\section{Spatial Autoregressive Model (SAR)}

TABEL 7. Hasil Uji Parameter Spatial Autoregressive Model (SAR)

\begin{tabular}{ccccc}
\hline Variabel & Koefisien & Standard Error & z-value & p-value \\
\hline Rho & 0,03699 & 0,01637 & 2,25941 & 0,02386 \\
Intercept & 5,67613 & 2,23879 & 2,53535 & 0,01123 \\
$\mathrm{X}_{1}$ & 0,41623 & 0,03380 & 12,3145 & 0,00000 \\
$\mathrm{X}_{2}$ & 1,36635 & 0,07289 & 18,7457 & 0,00000 \\
$\mathrm{X}_{3}$ & 1,04848 & 0,07535 & 13,9145 & 0,00000 \\
$\mathrm{X}_{4}$ & 0,00078 & $4,02485 \mathrm{e}-005$ & 19,3318 & 0,00000 \\
\hline
\end{tabular}

Berdasarkan TABEL 7 dapat dilihat bahwa koefisien $\rho$ bertanda positif dan signifikan pada $\alpha 0,05$ yang berarti ada keterkaitan atau hubungan antara nilai IPM di suatu wilayah dengan wilayah lainnya yang berdekatan. Selain itu, variabel Angka Harapan Hidup $\left(\mathrm{X}_{1}\right)$, Rata-rata Lama Sekolah $\left(\mathrm{X}_{2}\right)$, Angka Harapan Lama Sekolah $\left(\mathrm{X}_{3}\right)$ dan Kemampuan daya beli masyarakat $\left(\mathrm{X}_{4}\right)$ berpengaruh signifikan terhadap nilai IPM. Hal ini ditunjukkan oleh $p$-value dari masing-masing variabel $<\alpha 0,05$. Model Spatial Autoregressive Model (SAR) yang terbentuk dinyatakan pada persamaan (9). 


$$
y=0,03699 \sum_{i=1, i \neq j}^{n} w_{i j} y_{i}+0,41623\left(X_{1 i}\right)+1,36635\left(X_{2 i}\right)+1,04848\left(X_{3 i}\right)+0,00078\left(X_{4 i}\right)+\varepsilon_{i}
$$

Keterangan:

$\mathrm{y}_{\mathrm{i}} \quad$ : Nilai IPM di kabupaten/kota ke- $i$

$\mathrm{X}_{1 i}$ : Angka Harapan Hidup di kabupaten/kota ke- $i$

$\mathrm{X}_{2 i}$ : Rata-rata Lama Sekolah di kabupaten/kota ke- $i$

$\mathrm{X}_{3 i}$ : Angka Harapan Lama Sekolah di kabupaten/kota ke- $i$

$\mathrm{X}_{4 i}$ : Kemampuan daya beli di kabupaten/kota ke- $i$

$\mathrm{W}_{i j}$ : Matriks pembobot spasial tipe Queen Contiguity dengan $\mathrm{W}_{\mathrm{ij}}=1$ untuk wilayah yang ada di samping atau sudut wilayah yang diamati dan $\mathrm{W}_{\mathrm{ij}}=0$ untuk wilayah lainnya.

$\varepsilon_{i} \quad$ : Residual dari kabupaten/kota ke- $i$

Interpretasi dari model SAR tersebut adalah jika variabel lain dianggap konstan, setiap kenaikan 1 satuan variabel $\mathrm{X}_{1}$ (Angka Harapan Hidup) di suatu kabupaten/kota maka dapat meningkatkan nilai IPM sebesar 0,41623. Jika variabel lain dianggap konstan, setiap kenaikan 1 satuan variabel $\mathrm{X}_{2}$ (Rata-Rata Lama Sekolah) di suatu kabupaten/kota maka dapat meningkatkan nilai IPM sebesar 1,36635. Setiap kenaikan 1 satuan variabel $X_{3}$ (Angka Harapan Lama Sekolah) di suatu kabupaten/kota maka dapat meningkatkan nilai IPM sebesar 1,04848 jika variabel lain dianggap konstan. Setiap kenaikan 1 satuan variabel $\mathrm{X}_{4}$ (Kemampuan daya beli) di suatu kabupaten/kota maka dapat meningkatkan nilai IPM sebesar 0,00078 jika variabel lain dianggap konstan.

\section{Spatial Error Model (SEM)}

TABEL 8. Hasil Uji Parameter Spatial Error Model (SEM)

\begin{tabular}{ccccc}
\hline Variabel & Koefisien & Standard Error & $\boldsymbol{z}$-value & $\boldsymbol{p}$-value \\
\hline Lamda & 0,60106 & 0,12624 & 4,76108 & 0,00000 \\
Intercept & 5,46008 & 2,21631 & 2,46359 & 0,01376 \\
$\mathrm{X}_{1}$ & 0,45194 & 0,02993 & 15,0976 & 0,00000 \\
$\mathrm{X}_{2}$ & 1,30010 & 0,06209 & 20,9397 & 0,00000 \\
$\mathrm{X}_{3}$ & 1,09137 & 0,06552 & 16,6571 & 0,00000 \\
$\mathrm{X}_{4}$ & 0,00079 & $3,11607 \mathrm{e}-005$ & 25,3575 & 0,00000 \\
\hline
\end{tabular}

Berdasarkan TABEL 8 dapat dilihat bahwa koefisien $\lambda$ bertanda positif dan signifikan pada $\alpha 0,05$ yang berarti ada keterkaitan atau hubungan antara nilai IPM di suatu wilayah dengan wilayah lainnya yang berdekatan. Selain itu, variabel Angka Harapan Hidup $\left(\mathrm{X}_{1}\right)$, Rata-rata Lama Sekolah $\left(\mathrm{X}_{2}\right)$, Angka Harapan Lama Sekolah $\left(\mathrm{X}_{3}\right)$ dan Kemampuan daya beli masyarakat $\left(\mathrm{X}_{4}\right)$ berpengaruh signifikan terhadap nilai IPM. Hal ini ditunjukkan oleh $p$-value dari masing-masing variabel $<\alpha 0,05$. Model Spatial Error Model (SEM) yang terbentuk adalah sebagai berikut:

$$
\begin{gathered}
y=0,45194\left(X_{1 i}\right)+1,3001\left(X_{2 i}\right)+1,09137\left(X_{3 i}\right)+0,00079\left(X_{4 i}\right)+u_{i} \\
u_{i}=0,03699 \sum_{i=1, i \neq j}^{n} w_{i j} y_{i}+\varepsilon_{i}
\end{gathered}
$$

Keterangan:

$\mathrm{y}_{\mathrm{i}} \quad$ : Nilai IPM di kabupaten/kota ke- $i$

$\mathrm{X}_{1 i}$ : Angka Harapan Hidup di kabupaten/kota ke- $i$

$\mathrm{X}_{2 i}$ : Rata-rata Lama Sekolah di kabupaten/kota ke- $i$

$\mathrm{X}_{3 i}$ : Angka Harapan Lama Sekolah di kabupaten/kota ke- $i$

$\mathrm{X}_{4 i}$ : Kemampuan daya beli di kabupaten/kota ke- $i$

$\mathrm{u}_{i} \quad$ : Residual spasial dari kabupaten/kota ke- $i$ 
$\mathrm{W}_{i j}$ : Matriks pembobot spasial tipe Queen Contiguity dengan $\mathrm{W}_{\mathrm{ij}}=1$ untuk wilayah yang ada di samping atau sudut wilayah yang diamati dan $\mathrm{W}_{\mathrm{ij}}=0$ untuk wilayah lainnya

$\varepsilon_{i} \quad$ : Residual dari kabupaten/kota ke- $i$

Interpretasi dari model SEM tersebut adalah jika variabel lain dianggap konstan, setiap kenaikan 1 satuan variabel $\mathrm{X}_{1}$ (Angka Harapan Hidup) di suatu kabupaten/kota maka dapat meningkatkan nilai IPM sebesar 0,45194. Jika variabel lain dianggap konstan, setiap kenaikan 1 satuan variabel $\mathrm{X}_{2}$ (Rata-Rata Lama Sekolah) di suatu kabupaten/kota maka dapat meningkatkan nilai IPM sebesar 1,3001. Setiap kenaikan 1 satuan variabel $X_{3}$ (Angka Harapan Lama Sekolah) di suatu kabupaten/kota maka dapat meningkatkan nilai IPM sebesar 1,09137 jika variabel lain dianggap konstan. Setiap kenaikan 1 satuan variabel $\mathrm{X}_{4}$ (Kemampuan daya beli) di suatu kabupaten/kota maka dapat meningkatkan nilai IPM sebesar 0,00079 jika variabel lain dianggap konstan.

\section{Pemilihan Model Terbaik}

Kriteria kebaikan model yang digunakan dalam penelitian ini adalah dengan membandingkan nilai koefisien determinasi $\left(R^{2}\right)$ dan nilai AIC dari masing-masing model.

TABEL 9. Perbandingan Nilai $R^{2}$ dan Nilai AIC Model

\begin{tabular}{lcc}
\hline \multicolumn{1}{c}{ Model } & $\boldsymbol{R}^{2}$ & AIC \\
\hline Ordinary Least Square (OLS) & 0,997768 & 11,7784 \\
Spatial Autoregressive Model (SAR) & 0,998043 & 8,79079 \\
Spatial Error Model (SEM) & 0,998460 & 2,34578 \\
\hline
\end{tabular}

Berdasarkan TABEL 9 terlihat bahwa model SEM memiliki nilai $R^{2}$ terbesar yaitu 0,998460 dan nilai AIC terkecil yaitu 2,34578. Sehingga model SEM lebih baik digunakan dalam menganalisis nilai IPM di Provinsi Jawa Timur dibandingkan dengan model SAR dan model regresi OLS.

\section{Pengujian Asumsi Model}

TABEL 10. Hasil Uji Normalitas dan Heteroskedastisitas Residual Model SEM

\begin{tabular}{lcc}
\hline \multicolumn{1}{c}{ Uji } & Nilai & p-value \\
\hline Kolmogorov-Smirnov & 0,12594 & 0,13380 \\
Breusch-Pagan & 8,89550 & 0,06376 \\
\hline
\end{tabular}

Berdasarkan hasil uji asumsi kenormalan dan kehomogenan residual terlihat bahwa $p$-value dari hasil uji Kolmogorov-Smirnov $>\propto$ 0,05 maka keputusannya adalah $\mathrm{H}_{0}$ diterima yang berarti residual berdistribusi normal. Untuk uji Breusch-Pagan didapatkan $p$-value $>\propto 0,05$ maka keputusannya adalah $\mathrm{H}_{0}$ diterima yang berarti varian dari residual bersifat homogen. Sehingga dapat disimpulkan bahwa asumsi model SEM terpenuhi.

\section{KESIMPULAN}

Berdasarkan hasil dan pembahasan, peneliti memperoleh kesimpulan bahwa berdasarkan nilai uji Lagrange Multiplier (lag) dan Lagrange Multiplier (error) menunjukkan adanya dependensi lag dan error sehingga pemodelan SAR dan SEM lebih cocok digunakan dibandingkan model OLS. Berdasarkan hasil analisis SAR dan SEM terdapat perbedaan antara model SAR dengan model SEM yaitu pada koefisien regresi masing-masing variabel. Faktor yang berpengaruh terhadap nilai IPM di Provinsi Jawa Timur tahun 2017 pada model SAR dan model SEM adalah Angka Harapan Hidup, Ratarata Lama Sekolah, Angka Harapan Lama Sekolah dan Kemampuan daya beli masyarakat Pemilihan model terbaik didasarkan pada nilai $R^{2}$ dan nilai AIC dan didapatkan model SEM dengan nilai $R^{2}$ 
terbesar yaitu 0,998460 dan nilai AIC terkecil yaitu 2,34578 sehingga model SEM lebih baik digunakan untuk menganalisis nilai IPM di Provinsi Jawa Timur tahun 2017.

\section{UCAPAN TERIMA KASIH}

Penulis mengucapkan terima kasih kepada Badan Pusat Statistik Provinsi Jawa Timur yang telah menyediakan data untuk penelitian ini.

\section{REFERENSI}

Anselin, L. (1988). Spatial Econometrics: Methods and Models. Dordrecht: Kluwer Academic Publishers.

Badan Pusat Statistik. (2017). Indeks Pembangunan Manusia Provinsi Jawa Timur tahun 2017. Surabaya: BPS Provinsi Jawa Timur.

Badan Pusat Statistik. (2019). Indeks Pembangunan Manusia Provinsi Jawa Timur tahun 2019. Surabaya: BPS Provinsi Jawa Timur.

Fauzi, F. (2016). Model Regresi Spasial Terbaik Indeks Pembangunan Manusia Provinsi Jawa Tengah. Tugas Akhir, Universitas Negeri Semarang.

Lesage J., dan Pace, R.K. (2009). Introduction to Spatial Econometrics. Boca Raton, FL. Chapman \& Hall/CRC. 